\title{
THE TRANSMISSION OF LEARNED MEDICAL LITERATURE IN THE MIDDLE ENGLISH LIBER URICRISIARUM
}

by

JOANNE JASIN *

The Liber uricrisiarum in Wellcome MS 225 (hereafter, MS 225), a uroscopic treatise in Middle English that cites the De urinis by Isaac Judaeus as its principal source,' exemplifies the sort of vernacular medical literature produced in abundance in late fourteenth- and early fifteenth-century England that relies heavily on learned medical literature for its content. ${ }^{2}$ Especially striking in the Liber uricrisiarum are both the numerous citations throughout the text of other medical and scientific authorities and the parallels between these citations and the texts required for medical study at university in the fourteenth century. The fact that vernacular medical literature in medieval Europe is based largely on authoritative medical and scientific texts as opposed to popular medical lore is nothing new; ${ }^{3}$ moreover, it is evident that the use of the vernacular, i.e., Middle English, expanded the reading audience to include lay medical practitioners as well as university-educated physicians. ${ }^{4}$ What the

\footnotetext{
* Joanne Jasin, Ph.D., Department of English and Comparative Literature, California State University, Fullerton, California 92634, U.S.A.
}

This article, printed here in revised form, was originally presented as a paper under the title 'Vernacular medical texts in medieval England' in the colloquium series 'New findings in the history of science' ('Neue Ergebnisse der Wissenschaftsgeschichte') at the Institute for the History of Medicine of the Free University, Berlin, 27 June 1991.

I am grateful to Gerhard Baader for his valuable advice concerning the scope of this discussion in general and the issues of university curricula, Roger Frugardi, and the Anatomia vivorum in particular. My thanks are also extended to the anonymous reviewers of this article for their helpful suggestions for improvement; all errors and omissions are, however, my own. In addition, I would like to thank the Wellcome Institute for the History of Medicine for permission to work with Wellcome MS 225 and the British Library for permission to examine Sloane 1100 both in person and more recently on microfilm. I gratefully acknowledge the assistance of both the Luftbrückendank Foundation for research funding and the Institute for the History of Medicine of the Free University, Berlin, for research facilities in the preparation of this article.

\footnotetext{
' A Jewish physician and philosopher of the late ninth and early tenth centuries, Isaac Judaeus was highly regarded throughout the western Middle Ages as one of the foremost authorities on uroscopy and was also well known for his treatises on fevers and diet.

${ }^{2}$ MS 225 can be dated in the first quarter of the fifteenth century, based on internal evidence. It is written in a predominantly Northern dialect of Middle English, although some East Midland forms occur.

${ }^{3}$ See, for example, Linda Ehrsam Voigts, 'Medical prose', in A. S. G. Edwards (ed.), Middle English prose: a critical guide to major authors and genres, New Brunswick, Rutgers University Press, 1984, pp. 315-35, on p. 318; Gerhard Baader and Gundolf Keil, 'Einleitung', in Gerhard Baader and Gundolf Keil (eds), Medizin im mittelalterlichen Abendland, Darmstadt, Wissenschaftliche Buchgesellschaft, 1982, pp. 1-44, on p. 26; and Nancy G. Siraisi, Medieval and early Renaissance medicine, University of Chicago Press, 1990, p. 53.

${ }^{4}$ Baader and Keil, op. cit., note 3 above, pp. 26-7.
} 
Liber uricrisiarum in MS 225 also offers, though, is a statement of rhetorical purpose within the treatise proper which identifies the audience for whom the work was intended: "And all I wald undoo in common spech, pat all men myght undyrstand \& knaw, 3yf ony man wald fynd me my sustenaunce." 5 Though this declaration obviously includes lay practitioners among the treatise's potential readers, the phrase "all men" is so broadly worded that it may well indicate non-practitioners who would none the less be interested in uroscopy. This statement of purpose (not to mention the compiler's disclosure of his own financially impoverished state), together with the many citations of medical and scientific authorities, indicates a vernacular text that intentionally makes available to a wide audience knowledge that medieval physicians acquired in pursuing a course of study in medicine at university. To be sure, the Liber uricrisiarum does not transmit all such knowledge word for word as it appears in the original Latin texts, even when the compiler may declare that he has translated his source "nerhand word for worde", 6 as the compiler of the Liber uricrisiarum says of Isaac's De urinis. Instead, he typically edits and revises the technical information in his sources in order to adapt it to the practical needs and limitations of the lay members of his audience. ${ }^{7}$ The resulting vernacular text thus conveys to its readers medical knowledge regarded as authoritative in medieval Europe, but does so in a manner and form that modifies that knowledge to some extent in tailoring it to its audience.

That the Liber uricrisiarum was created with a lay readership in mind is supported by certain statements in a prologue to the treatise, originally written in Latin and later translated into Middle English. Though the text in MS 225 lacks a prologue-apparently omitted by the scribe, rather than missing - the close parallels in content, structure, and wording between MS 225 and other manuscript versions of the Liber uricrisiarum accompanied by a prologue attest its applicability to the text in MS 225. In its opening lines, the prologue identifies Henry Daniel, a Dominican friar of the late fourteenth century, as the translator of the treatise. ${ }^{8}$ Among the points relevant to the issues of rhetorical purpose and audience that Daniel makes in the prologue are the unavailability of works in English on uroscopy, his recognition of the value of uroscopy as a science, and his desire to provide

\footnotetext{
5 Joanne Jasin, 'A critical edition of the Middle English Liber uricrisiarum in Wellcome MS 225', PhD thesis, Tulane University, 1983; Ann Arbor, Michigan, University Microfilms International, 1984; p. 142. This statement of purpose occurs not at the beginning of the Liber uricrisiarum, where one would expect it, but rather on $30^{r}$ (the treatise occupies ff. $5^{r}-143^{v}$ in the manuscript). I have drawn all subsequent quotations from the Liber uricrisiarum in MS 225 from this edition of the manuscript. In the edition, expansion of all abbreviations and suspensions in the manuscript is indicated by italics. I have followed modern conventions in adding punctuation. Alternate readings provided by the compiler or scribe appear in parentheses. Underlining indicates occurrences of scribal underlining; I have deliberately not underlined other words or phrases in the treatise to avoid confusion with scribal underlining. I completed the thesis working solely from microfilm; the quotations provided here, however, incorporate revisions based on my subsequent examination in person of the original manuscript at the Wellcome Institute for the History of Medicine in London.

' Ibid., p. 483.

${ }^{7}$ The compiler of the Liber uricrisiarum is not unique in his practice of revising and adapting sources in rendering them into the vernacular; see, for example, the remarks of Faye Marie Getz concerning the Middle English version of Gilbertus Anglicus in Healing and society in medieval England: a Middle English translation of the pharmaceutical writings of Gilbertus Anglicus, Madison, University of Wisconsin Press, 1991, pp. xliv-xlviii. Getz suggests other reasons for the revision evident in the Middle English Gilbertus Anglicus, as does Peter Murray Jones in discussing vernacular translations of John of Arderne in 'Four Middle English translations of John of Arderne', in A. J. Minnis (ed.), Latin and vernacular: studies in late-medieval texts and manuscripts, Proceedings of the 1987 York manuscripts conference, Cambridge, D. S. Brewer, 1989, pp. 61-89, on p. 63.

${ }^{*} I$ refer to the Latin version of the prologue in Sloane 1100, British Library, f. $1-1^{2}$.
} 


\section{The Middle English Liber uricrisiarum}

access to the benefits that knowledge of uroscopy would offer to those who did not know Latin. These statements, consistent with the declaration of rhetorical purpose in MS 225 cited above, imply a keen awareness on the part of Daniel, serving here as both compiler and translator, of the utility of his contributions to medieval readers. Among other important factors motivating Daniel in his scholarly and linguistic endeavour, Faye Marie Getz credits the "charitable impulses of the medieval preaching friars" with encouraging him to translate the Liber uricrisiarum; she notes his references to charity in the prologue and his special suitability as a friar (i.e., one who had taken a vow of poverty) to dispense medical knowledge for the good of humanity rather than material gain. ${ }^{9}$ Getz also points to a tradition in Latin, preceding Daniel by a century, of writing medical texts as a demonstration of charity toward fellow human beings. ${ }^{10}$

Yet Daniel's prologue also raises the issue of the limited capacity of the vernacular to communicate scientific knowledge, even as the completed treatise itself stretched the capacity of fourteenth-century English to convey scientific concepts and technical knowledge. Indeed, Daniel's decision to write the prologue originally in Latin rather than English suggests a deference to convention seemingly inconsistent with his intention to make the science of uroscopy more widely accessible than it previously had been. " Yet, as Ralph Hanna III points out in his discussion of the prologue, Daniel's assertion that he has collected the "marrow" of the science of uroscopy in his treatise forcefully implies his belief in the potential of English to transmit learned knowledge with clarity. ${ }^{12}$

The Liber uricrisiarum is an early and significant example of the Ricardian translations, as Hanna states; moreover Daniel, in questioning the capability of English to convey sophisticated medical learning, raises concerns about language shared by other such translators. ${ }^{13}$ The methods of translation that Daniel employs throughout the treatise demonstrate how he responds to those concerns; at the same time, they reveal his careful attention both to the learned material he was translating and to the lay audience that would read it. One of the more frequently used techniques appearing throughout the text in MS 225 is the use of synonyms and glosses to translate Latin terminology, a key trait of the Trevisa translations and one discussed both by Getz in her introduction to the Middle English translation of Gilbertus Anglicus and by Peter Murray Jones in his analysis of

\footnotetext{
9 Faye Marie Getz, 'Charity, translation, and the language of medical learning in medieval England', Bull. Hist. Med., 1990, 64: 1-17, pp. 17 and 14. Getz also states that Dominican friars in particular translated vernacular medical texts for this reason (pp. 8-9). In quoting from Daniel's prologue, she uses the Middle English version in Royal MS 17.D.1, British Library.

i) Ibid., p. 9. She cites the Thesaurus pauperum and the Micrologus as examples of this tradition.

" None the less, by writing in Latin Daniel does not deny those readers literate only in the vernacular any information on uroscopy itself, apart from a summary at the end of the prologue of the three-part structure of the treatise. Of course, the later translation of the prologue into Middle English meant that vernacular readers could also ponder Daniel's comments on rhetorical purpose and language, among other matters.

12 Ralph Hanna III, 'Henry Daniel's Liber uricrisiarum (excerpt)', in Lister M. Matheson (ed.), Popular and practical science of medieval England, East Lansing, Colleagues Press, forthcoming, 1993, pp. 185-218. Hanna provides an edition of the first three chapters in Book One of the treatise (equivalent to the first five chapters in MS 225), based on the text in HM 505 in the Huntington Library in San Marino, California. Though this excerpt is not accompanied by an edition of the prologue, Hanna quotes extensively from the Middle English version of the prologue in MS e Musaeo 187 in the Bodleian Library. I am very grateful to Professor Hanna for providing me before publication with a copy of his essay containing the edited excerpt.

${ }^{13}$ Ibid, pp. 185-6, 189-90.
} 
Middle English translations of John of Arderne. ${ }^{14}$ Synonyms and glosses in MS 225 are often signalled by the Latin abbreviation for id est in the manuscript (.i.) and translate, respectively, anglicized Latin words and terms left in the original Latin (note, for example, the synonym provided for the Middle English aquosyte: "id est, pe watryhede" [Lat. aquositas]; and the gloss for suffocacio: "a stuffynge, a strangulynge, a chokynge"). ${ }^{15}$ The translation in MS 225 shares other features with the Gilbertus translation, including a reliance on explanation to clarify an anglicized Latin word ${ }^{16}$ and the occasional use of an analogy not appearing in the Latin source, also for the sake of clarification. This latter characteristic resembles the instances of concrete imagery occurring in the Middle English Gilbertus $;{ }^{17}$ it sometimes appears in MS 225 , for example, in descriptions of the colours of urine where it would be especially useful, since MS 225 contains no illustrations representing the various colours and thus relies on words rather than images to make such distinctions for the reader. ${ }^{18}$

Where the text in MS 225 differs strikingly from the Middle English versions of Gilbertus and John of Arderne, however, is in the extensive use of etymologies as a translation device. ${ }^{19}$ As with the other methods of translation noted above, Daniel demonstrates in a very tangible way his intent to make complex concepts and detailed technical information accessible to a wide readership by rendering them as clearly as possible-a necessary approach, if he is to achieve the goal expressed in his prologue of providing readers with a work they could use. In this case, though, his inclusion of medieval etymologies of certain terms seems to go one step further and reflects the attention in the prologue to the problem of language in general and English in particular as a means of conveying full knowledge of uroscopy, namely, that written texts cannot substitute entirely for actual experience if one is to learn the science properly. ${ }^{20}$ On this issue Daniel is simply repeating the opinion of Averroes and Gilbertus (he names both at this point in the prologue), but at the same time he reveals his own interest in complex issues of language. The numerous etymologies in MS 225 function as both a rather

${ }^{14}$ Getz, op. cit., note 7 above, p. xlvi; Jones, op. cit., note 7 above, pp. 84-6.

15 Jasin, op. cit., note 5 above, pp. 117 and 189, respectively. The word aquosyte exemplifies the distinction Getz makes between "importations" from Latin and actual translations (Getz, op. cit., note 7 above, p. xlvi).

${ }^{16}$ Compare the explanations for the Latin ptisana in Gilbertus, "Ptisane is watir pat barliche is soden yn" (Getz, op. cit., note 7 above, pp. xlvi and 108); and in MS 225, "a drynk pat we call a pthisan, or water styllyt owt of herbys" (Jasin, op. cit., note 5 above, p. 56). Though the word "pthysan" appears at this same point in the text in Hanna's edited excerpt, the explanation does not. (Hanna, op. cit., note 12 above, p. 198.)

${ }^{17} \mathrm{Getz}$, op. cit., note 7 above, p. xlvii.

is Note the description provided in MS 225 of the colour inopos: "[I]nopos colour is mast lyk wyn, thyk \& blakyssh as wyn of Calabre or ellys wyn [of] Grece, or ellys lyk mody water pat is swart \& redyssh, as pu seis in sum cuntris pare pe sole is redyssh ..." (Jasin, op. cit., note 5 above, p. 352). Manuscript illustrations of the colours of urine can be found in Siraisi, op. cit., note 3 above, p. 126; in Linda Ehrsam Voigts, 'Scientific and medical books', in Jeremy Griffiths and Derek Pearsall (eds), Book production and publishing in Britain, 1375-1475, Cambridge University Press, pp. 345-402, on p. 376; and in Peter Murray Jones, Medieval medical miniatures, London, British Library in association with the Wellcome Institute for the History of Medicine, 1984, pp. $65,70$.

${ }^{19}$ Note, for example, the etymological explanation provided for ypostasis, a kind of sediment in urine: "Ypostasy's is said of pis word of Grece / ypos, id est, sub, id est, undyr or beneth, \& of pis word [of] Grece stasis, id est, posicio, id est, standynge or puttynge, as wha say a standynge beneth" (Jasin, op. cit., note 5 above, p. 458). Interestingly, here Latin is used as a bridge between Greek and Middle English. For further discussion of etymology in MS 225, see Joanne Jasin, 'The compiler's awareness of audience in medieval medical prose: the example of Wellcome MS 225', Journal of English and Germanic philology, forthcoming, 1994.

2) This issue is discussed by Hanna, op. cit., note 12 above, pp. 189-90; Getz, op. cit., note 9 above, p. 15. 
sophisticated method of translation and a creative-and learned-response to the linguistic challenge Daniel encountered in producing the Liber uricrisiarum.

We can infer certain generalizations from the Liber uricrisiarum as a whole regarding Daniel's overall plan for the work and his priorities, such as the pragmatic concerns of his lay readers mentioned above. Daniel clearly places great value on a comprehensive treatment of his subject. Not content with merely providing a crude list of the colours of urine and the diseases they signify (of course, Isaac's treatise itself offers much more than this), he discusses a variety of other subjects appropriate to diagnosis, including the four humours, nutrition, digestion, astronomy, and gynaecology. Moreover, the text is obviously a product of its time: its concept of disease and health is based entirely on the theory of the four humours and it regards urine, the by-product of the second digestion, as the essential means whereby an imbalance of the humours, and thus disease, can be detected. The compilatory approach to uroscopy, characterized by extensive reliance on established medical authorities, places the Liber uricrisiarum well within the scholastic tradition of the Middle Ages.

The name of the compiler and translator of the uroscopy in MS 225 does not appear anywhere within the treatise itself, although the name "Henry Daniel" is written in a modern hand on the inside cover of the manuscript, along with the title "Liber uricrisiarum" (found also in the treatise, in the scribe's hand) and the words "early 15th century". The attribution to Henry Daniel, a fourteenth-century Dominican friar, is most likely based on evidence contained in MS Ashmole 1404 in the Bodleian Library, a manuscript of the Liber uricrisiarum, ascribed in Latin to Henry Daniel and dated 1379. ${ }^{21}$ Twenty-two versions of Daniel's treatise are to be found among existing uroscopies in Middle English, some with an ascription to the Dominican friar and some without. ${ }^{22}$

21 S. A. J. Moorat, Catalogue of western manuscripts on medicine and science in the Wellcome Historical Medical Library, vol. I: MSS written before 1650 A.D., London, Wellcome Historical Medical Library, 1962, p. 143.

22 Thomas Kaeppeli in fact lists 23 texts of the Liber uricrisiarum in his entry for Henry Daniel, one of which (Hunterian Mus. U. 8.30, f. 1-83 , at the University of Glasgow) is in Latin instead of Middle English. In addition to MS 225, Kaeppeli lists the following manuscripts: (1) Boston, Massachusetts, Hist. Soc. 1; (2) *Brussels, Bibl. Royale IV 249; (3) and (4) Cambridge, Gonville and Caius Coll. 180, f. 1-161'; and 376, f. 1-169'; (5) Cambridge, St John's Coll. 38, f. 1-96; (6) Cambridge, Trinity Coll. 1473, f. 1-99; (7) and (8) Cambridge, Univ. Libr. Ff. II. 6, f. 1-128; and Gg. Ill. 29; (9) *Gloucester, Cathedral Libr. 19; (10 to (15) Brit. Libr.: *Royal 17.D.1; *Egerton 1624, f. 12v-108, 122-213; *Sloane 340, f. 40-63v; Sloane 1100, f. 1-119 (or 3-121; this numbering in a modern hand also appears in the upper corners of the manuscript); *Sloane 1721; and Sloane 2527, f. 179-196; (16) London, Royal Coll. of Physicians 356, f. 1-64 ; (17) London, Wellcome Institute for the History of Medicine, 226, f. 1-70v; (18) to (20) Oxford, Bodl. Libr.: Ashmole 1404, f. 3-184; e Mus. 116, f. 65; e Mus. 187; (21) San Marino, California, Huntington Libr., HM 505 (Thomas Kaeppeli, Scriptores ordinis praedicatorum medii aevi, vol. 2, Rome, S. Sabina, 1970, p. 192). Sloane 1100 and HM 505 each give Daniel's Latin prologue; Royal 17.D.1 and e Mus. 187, its Middle English version. Sloane 340 provides only a fragment of the treatise; Wellcome MS 226 is also incomplete, ending with Chapter Eight of Book Two and thus omitting Book Three of the treatise altogether, along with several chapters of Book Two. Hanna describes Kaeppeli's list as accurate but provides some corrections and additional detail for several manuscripts; I have indicated those with an asterisk (Hanna, op. cit., note 12 above, pp. 190-1). Hanna and I both note the sixteenth-century printed version of Daniel's uroscopy entitled Judycyall of uryns (STC 14836; Jasin, op. cit., note 5 above, pp. 12-13).

Of the 34 uroscopies in Middle English that Rossell Hope Robbins has identified, several are fragments, and only six in his list correspond to the manuscripts of Daniel's version in Kaeppeli (Rossell Hope Robbins, 'Medical manuscripts in Middle English', Speculum, 1970, 45: 393-415, p. 399). Voigts provides a supplement to Robbins' list, though it, too, is a partial list (lacking reference to Sloane 1100, for example; see Voigts, op. cit., note 3 above, pp. 328-9). A completed Index of Middle English prose, a project begun in 1980 and still in progress, may very well bring to light other Middle English uroscopies. 
Since, as has been noted, the text in MS 225 appears without a prologue, the lack of an ascription to Daniel contemporary with the manuscript is understandable, since such matters are typically part of a prologue. ${ }^{23}$ Yet the parallels between MS 225 and other versions of Daniel's text containing a prologue ${ }^{24}$ are certainly close enough to leave little doubt, if any, that the Liber uricrisiarum in MS 225 is indeed the work of Henry Daniel. ${ }^{25}$ In addition, the compiler's reference to "myn awn ordor" near the end of MS 225 reinforces the connection between Daniel and the compiler of the text in MS 225 as a member of a religious order. ${ }^{26}$

We know very little about Henry Daniel. ${ }^{27} \mathrm{He}$ is listed in both the Dictionary of national biography and Talbot and Hammond's register of medical practitioners in medieval England, in the latter as physician and Dominican friar. ${ }^{28}$ What little we do know has been gleaned principally from the medical manuscripts in which his name appears: he lived around 1379 (the year he completed the Liber uricrisiarum) and produced two other medical texts in addition to the uroscopic treatise, one entitled Aaron Danielis, on the medicinal properties of various herbs, and the other a translation of a treatise on the properties of rosemary. ${ }^{29}$ We do not know whether he studied medicine. ${ }^{30}$

\footnotetext{
${ }^{2.3}$ Including Daniel's dedication of the text to Master Walter Tournour of Keten; according to Talbot and Hammond's register of medical practitioners in medieval England, this dedication appears in thirteen other manuscripts containing Daniel's uroscopic text. See Charles H. Talbot and E. A. Hammond, The medical practitioners of medieval England: a biographical register, London, Wellcome Historical Medical Library, 1965, p. 79. Getz provides corrections and additions to this entry for Daniel in 'Medical practitioners in medieval England', Soc. Hist. Med., 1990, 2: 245-83, pp. 260-1.

${ }^{24}$ E.g., Sloane 1100 and HM 505. As stated earlier, these parallels exist in the content, structure, and wording of the corresponding manuscript versions. An advantage of MS 225 is that it provides a complete text of the Liber uricrisiarum, with the exception of two figures mentioned in the text but not inserted (one of a wheel used in calculating leap year and the other of the rota celi or rota mundi, presumably depicting the Ptolemaic universe). Two blank folios in Sloane 1100 make its version of the Liber uricrisiarum incomplete; moreover, it lacks the internal statement of rhetorical purpose in MS 225 that is quoted above. The other differences between the two versions are primarily linguistic and stylistic in nature: Sloane 1100 is written in a predominantly East Midland dialect instead of the Northern dialect of MS 225; in addition, the treatise in MS 225 provides somewhat more explanation of technical terms in the form of synonyms or analogies than does the text in Sloane 1100.

${ }^{25}$ Hanna points out the existence of numerous scribal additions in MS 225 and Ashmole 1404, and for this reason among others chooses the text in HM 505 for his edition of the first portion of Daniel's treatise. Admittedly, such additions raise the issue of distinguishing between the translator's text and the scribe's, yet in the case of MS 225 it appears that most of what can be called scribal additions follow the spirit of Daniel's rhetorical purpose and sense of audience, typically taking the form of additional synonyms and glosses, explanations of technical terms, etymologies, and cross-referencing; they provide material that itself demands attention and analysis. Consider, for example, the material in Book One of MS 225, which expands this first part of the treatise well beyond the four chapters Daniel specifies in both the Latin and English versions of his prologue, to 19 chapters: from Chapter Six to the end of Book One, the text takes up one by one the 20 condicions that the practitioner must heed in examining urine since they properly affect diagnosis, including obvious matters like the patient's gender and diet, as well as others such as emotional state and bathing habits. That scribal additions do not necessarily mean debasement of the text is pointed out by Voigts, op. cit., note 18 above, p. 350 .

${ }^{26}$ Jasin, op. cit., note 5 above, p. 457.

27 See Hanna, op. cit., note 12 above, pp. 186-8, for additional biographical information about Daniel.

${ }^{28}$ Sir Leslie Stephen and Sir Sidney Lee (eds), Dictionary of national biography, London, Oxford University Press, 1917; Talbot and Hammond, op. cit., note 23 above, p. 79.

${ }_{29}$ Talbot and Hammond, op. cit., note 23 above, p. 79.

30 A. B. Emden's biographical register for Oxford University lists a Henry Danyell who was ordained into the clergy and granted permission in 1453 to study at Oxford for one year, yet he does not seem to be the Henry Daniel associated with the Liber uricrisiarum; his date of study at Oxford and his date of death (1458) do not coincide with the date of 1379 in certain manuscripts of the uroscopy, and there is no mention of his having studied medicine. Emden's register for Cambridge University provides no relevant information. See A. B.
} 
Yet the contents of the Liber uricrisiarum point to a man learned in medicine, who may well have studied medicine at Oxford, given the parallels between the medical authorities cited in MS 225 and the medical curriculum at Oxford in the late fourteenth century. Other parallels between citations in the text and medical works and authorities associated with Italy or France also raise the possibility of Daniel's having travelled to the Continent to pursue medical studies.

As a Dominican friar, Daniel belonged to a mendicant order in which education occupied a central position, thus creating a likely and hospitable environment in which to acquire the learning that the Liber uricrisiarum transmits. ${ }^{31}$ Daniel's status as cleric itself strengthens the possibility of his having studied medicine formally since, as Huling E. Ussery has pointed out, the student at university who had not taken orders was the exception rather than the rule. ${ }^{32}$ Vern L. Bullough has also suggested that more students in medieval Oxford must have acquired medical knowledge than records of actual degrees awarded in medicine would indicate, through ownership of medical manuscripts, for example, or later acquisition of the titles medicus or physicus, despite no documented association with the medical school. ${ }^{33}$ Moreover, the prominent role played by English monasteries in the translation and dissemination of Arabic learning in medieval England increases the likelihood of Daniel's access to medical and scientific (e.g., astronomical) texts by Arabic authorities. ${ }^{34}$ In short, although Daniel's status as a student of medicine at university remains unproven, these various factors make a plausible case for his access to the learned texts cited in the Liber uricrisiarum.

Despite the statement in MS 225 that the compiler has rendered Isaac Judaeus' treatise on urines "nerhand word for worde" into Middle English-as if to imply that the text

Emden, A biographical register of the university of Oxford to A. D. 1500, Oxford, Clarendon, 1957-59, p. 542; and $A$ biographical register of the university of Cambridge to 1500, Cambridge University Press, 1963.

${ }^{31}$ William J. Courtenay has examined the significant role of the mendicant orders in medieval England in the development of Oxford and Cambridge universities, and in particular of the Dominican and Franciscan convents in fourteenth-century Oxford. Though the Franciscans were on a par with the Dominicans in founding convents in areas that would develop a reputation as academic centres, the Dominicans were the only mendicant order to be established with a firm commitment to learning. A student within the Dominican system was educated even at the level of the studium artium according to standards similar to those at university, and at the next level, the studium naturalium, would study Aristotle's scientific texts, as would the Oxford student. By the fourteenth century the Dominicans had established a university convent at Oxford (in addition to convents at Cambridge, London, and York), which in 1377 counted seventy resident friars. The Oxford convent was the most important of the Dominican convents (due mainly to the prestigious position of Oxford University within England) and was, consequently, the only one offering all levels of study: the studium artium, studium naturalium, and studium theologiae. Courtenay characterizes the Dominicans as the intellectual equals of the Franciscans in the thirteenth century - the Dominicans counted Nicholas Trevet, known for his commentaries on Boethius, and cited in MS 225, among their numbers-but acknowledges that they lost ground intellectually to the Franciscans in the fourteenth century. See William J. Courtenay, Schools and scholars in fourteenth-century England, Princeton University Press, 1987, pp. 61-6.

${ }^{32}$ Ussery states, “. . . those persons who had any formal education in medicine were almost certainly clerics". See Huling E. Ussery, Chaucer's physician: medicine and literature in fourteenth-century England, New Orleans, Tulane University, 1971, p. 29.

${ }^{33}$ Vern L. Bullough, 'Medical study at medieval Oxford', Speculum, 1961, 36: 600-12, pp. 604-5.

${ }^{34}$ Hans Hugo Lauer points out that one must look beyond the universities to the monasteries for an accurate picture of the reception of Arabic learning in medieval England. Arabic medical authorities are represented first in book collections in monasteries and only later in university reading lists; a booklist for St Andrew's Priory, Rochester, for example, provides an entry for the Arabic physician Rhasis as early as 1202. Monasteries were not 


\section{Joanne Jasin}

contains material from no other source-the wealth of references to other medical and scientific authorities makes clear that Daniel has drawn on many other sources in addition to Isaac's De urinis in producing the Liber uricrisiarum. ${ }^{35}$ They attest the breadth and depth of his reading, revealing an individual steeped in the established medical learning of his day and thus prepared in that important respect to transmit such learning to his audience. A significant proportion of these sources, existing in Latin translation and known as the Articella, represents the basis for medical instruction at such important centres for the study of medicine in Europe as Salerno (from the twelfth century), ${ }^{36}$ Bologna (in the thirteenth century), Paris (from 1190 to 1350 ), ${ }^{37}$ and Montpellier (from 1240). ${ }^{38}$ Those names cited in MS 225 that point to Daniel's direct contact with works in the Articella include, in addition to De urinis, Isaac's De febribus; the treatise on urines by Theophilus; ${ }^{39}$ the Aphorisms and the Prognostics by Hippocrates; a pulse treatise most likely by Philaretus, though he is not cited by name in MS 225; the Isagoge by Johannitius; ${ }^{40}$ and Constantinus Africanus. ${ }^{41}$ These references encompass most of the works of the Articella; only the Diaetae particulares et universales by Isaac, the Hippocratic Regimen acutorum, and the commentary by Haly Rodoan (Ali ibn Ridwan) on Galen's Ars parva are not cited in MS $225 .{ }^{42}$ (One reference to "Haly" and his "Prospectyf" does appear in the Liber uricrisiarum, but it is unclear whether the name refers to the Egyptian physician and astrologer of the eleventh century mentioned here; to Haly Abbas [Ali ibn al-Abbas al-Magusi], the tenth-century Persian physician; or to another medical authority so named.) Another work cited in MS 225 (though infrequently) and included in some Articella manuscripts is the Epidemics by Hippocrates, of which only the sixth book was translated in the thirteenth century from Arabic into Latin by

only collectors, however; the twelfth-century cleric Daniel of Morley travelled to Toledo after his studies at Oxford and became a student of Gerard of Cremona before returning to England. He translated works by Johannitius, Isaac Judaeus (i.e., Isaac's philosophical rather than medical treatises), and Alfraganus. See Hans Hugo Lauer, 'Zur Beurteilung des Arabismus in der Medizin des mittelalterlichen Englands', Sudhoffs Archiv, 1967, 51: 326-48, pp. 343, 338.

35 In his prologue, Daniel names Galen, Gilles de Corbeil, Gilbertus Anglicus (known also for his commentary on Gilles), Constantine, and Theophilus along with Isaac as his sources, all of whom he cites in the treatise; he makes a general reference to "other authors" as well (Sloane 1100, f. 1").

${ }^{36}$ Paul Oskar Kristeller discusses the development of the Articella in his essay 'The school of Salerno: its development and its contribution to the history of learning', in Studies in Renaissance thought and letters, Rome, Edizioni di Storia e Letteratura, 1956, pp. 495-551, on pp. 508-15; see also Kristeller's more recent full-length study of Salerno, Studi sulla scuola medica salernitana, Naples, Istituto italiano per gli studi filosofici, 1986.

${ }^{37}$ Gerhard Baader, 'Die Schule von Salerno', Medizinhistorisches Journal, 1978, 13: 124-45, pp. 134-5.

${ }^{38}$ Vern L. Bullough, 'The development of the medical university at Montpellier to the end of the fourteenth century', Bull. Hist. Med., 1956, 30: 508-23, p. 513.

${ }_{39}$ The seventh-century Greek physician who, along with Isaac Judaeus, was a leading authority on uroscopy in the Middle Ages.

40 The Latinized name for Hunain ibn Ishaq, the ninth-century Nestorian physician whose Isagoge is an introduction to the Ars parva of Galen.

41 The eleventh-century monk at Monte Cassino, briefly associated with the medical faculty at Salerno, noted chiefly for his translations from Arabic into Latin of medical treatises; his Latin translations are the ones contained in the Articella. Isaac's medical treatises, including De urinis, were originally written in Arabic. Herbert Bloch provides both biographical information on Constantine as well as discussion of his contributions to the Articella in Monte Cassino in the Middle Ages, Cambridge, Mass., Harvard University Press, 1986, vol. 1, pp. 98-110.

42 These last two works appear in many, though not all, Articella manuscripts; see Baader, op. cit., note 37 above, p. 134. 


\section{The Middle English Liber uricrisiarum}

Simon of Genoa, personal physician to Pope Nicholas IV. ${ }^{43}$ Completing the references to Hippocrates, the citation of his "Buk of uryns" in MS 225 may indicate the Epistola de urinis attributed to Hippocrates, one of the many Epistolae ascribed to him that circulated in the Middle Ages. ${ }^{44}$

Daniel's citation of these medical authorities and their works reflects his thorough knowledge of the foundations of medical learning in the Middle Ages, since they comprise the basis of formal medical instruction from the twelfth century onward in Salerno and elsewhere, including Oxford and Cambridge. ${ }^{45}$ The reading list for medical students at Cambridge in the late fourteenth century consisted only of the Articella, indicating that although Cambridge required of its students the basis in medical knowledge established at Salerno two centuries earlier, it did not go beyond that foundation. ${ }^{46}$ Much more relevant to the citations appearing in the Liber uricrisiarum in MS 225 are the known medical texts at Oxford during the same period: they show Oxford's connection with some of the newer developments in medical training on the Continent and also establish the learned context out of which the Liber uricrisiarum developed. They suggest too that Daniel may have gained access to the texts by studying medicine at Oxford. The medical books bequeathed in 1372 to various Oxford colleges by Simon Bredon, student, doctor of medicine, and astronomer at Oxford, ${ }^{47}$ suggest the curriculum in medicine there as they provide answers to the question of availability for a number of the references in MS 225. Of particular interest are those names that go beyond the standard list of works comprising the Articella. Among the medical authorities cited in the Liber uricrisiarum that were thus available at Oxford from 1372 onward was Avicenna (Ali ibn Sina), ${ }^{48}$ whose work was also required reading for medical students at Montpellier under the university statutes of $1240 .{ }^{49}$ Others included Gilbertus Anglicus, whose Practica Bredon donated to Merton; and Taddeo Alderotti, thirteenth-century magister in the medical faculty at Bologna, whose work on the Aphorisms Bredon also bequeathed. ${ }^{50}$

\footnotetext{
${ }^{43}$ Gerhard Baader, 'Die Tradition des Corpus Hippocraticum im europäischen Mittelalter', in Gerhard Baader and Rolf Winau (eds), Die Hippokratischen Epidemien, Sudhoffs Archiv, no. 27, Stuttgart, Franz Steiner, 1989 , pp. 409-19, on pp. 416-17. Baader points out that relatively few of the many works attributed to Hippocrates became part of standard medical literature in medieval Europe. Pearl Kibre states that Latin translations of the sixth book of the Epidemics, a work more likely of Cnidian than Coan origin, exist in thirteenth- and fourteenth-century manuscripts. See Pearl Kibre, 'Hippocratic writings in the Middle Ages', Bull. Hist. Med., 1945, 18: $371-412$, p. 396.

${ }^{44}$ Kibre, op. cit., note 43 above, pp. 402-3.

45 Further indication of Daniel's familiarity with Salerno is his reference, appearing only once in the text in a discussion of the "pety emitrice" ("emitrice", according to the Middle English dictionary, is a type of intermittent fever), to several Salernitan magistri, some of whom were associated with Salerno at the high point of its development in the twelfth century: Joannes Ferrarius ("Maister Frerys"); Platearius ("Maister Planetary"), either Matthew or Joannes; Johannes of Sancto Paulo ("Maister Jone of Sant Paulys"); and Petrus Musandis ("Maister Perys Massendoun").

${ }^{46}$ Vern L. Bullough, 'The mediaeval medical school at Cambridge', Medicieval Studies, 1962, 24: 161-8, p. 165; see also Damian Riehl Leader, A history of the university of Cambridge, vol. 1, The university to 1546 , Cambridge and New York, Cambridge University Press, 1988.

${ }^{47}$ Bullough, op. cit., note 33 above, pp. 607-8; Talbot and Hammond, op. cit., note 23 above, pp. $320-2$.

${ }^{48}$ Bullough, op. cit., note 33 above, p. 607 . Bredon's will does not specify the title of Avicenna's work to be bequeathed but states only, “.... lego Auicennam meum meliorem ...”.

${ }^{49}$ Idem, op. cit., note 38 above, pp. 515-16.

50 MS 225 mentions two additional figures, Bernard of Gordon (magister at Montpellier in the late thirteenth and early fourteenth centuries) and Lanfranc (thirteenth-century surgeon associated with Milan), though he uses neither as a source. He instead refers to both as authorities whose works (he specifies Bernard's Lilium) he should
} 


\section{Joanne Jasin}

Bredon's bequest does not include an entry for Gilles de Corbeil, the twelfth-century magister at Montpellier known throughout medieval Europe for his verse on urine. Yet Daniel's reference in the prologue both to Gilles, and to Gilbertus' commentary on Gilles and the numerous citations of both in MS 225 indicate his access to, and use of these works. ${ }^{51}$ Daniel's reliance on Gilles in particular strengthens the connections between the Middle English treatise and Montpellier.

One other medical work cited in MS 225 points directly to Paris rather than Montpellier, namely, the Anatomy attributed to Galen ("Buk of anothomiis" in MS 225) which is in fact the Anatomia vivorum. ${ }^{52}$ The work appears together with other texts attributed to Galen in a Balliol College manuscript (number 231) of the same Paris provenance as the manuscript in the Paris university library (number 125). It became part of the Balliol College collection in 1335 as a gift of Stephen of Cornwall, who studied medicine at Oxford in the early fourteenth century and later became doctor of medicine at the University of Paris. ${ }^{53}$ The Anatomia vivorum consists of material drawn principally from Avicenna (his Canon, or al-Qanun) and Rhasis (ar-Razi; the Liber ad almansorem, or K. al-Mansuri) translated into Latin at Toledo; it systematizes available knowledge in the scholastic manner rather than making new contributions to anatomical knowledge. ${ }^{54}$

One name in MS 225 indicates Daniel's access to the work of a figure highly regarded in the field of surgery, namely, Roger Frugardi of Parma. Often associated with Salerno-an association now shown to be erroneous ${ }^{55}$ - Roger is best known for his Chirurgia, a work chiefly practical rather than theoretical in nature and widely used after its appearance in the twelfth century. ${ }^{56}$ Two citations of Roger in the Liber uricrisiarum appear not in any surgical context, however, but rather in a description of the types and symptoms of leprosy, a topic that Roger treats in the fourth book of the Chirurgia. Though Daniel does not include the material on surgery for which Roger Frugardi is most recognized, he does select that portion of the Chirurgia best suited to a uroscopic text. ${ }^{57}$

read but simply cannot afford to buy: "Gorgonie of Burgundie pat is called Lilium Medicine, ne Lamfrank, ne syk oper new autors, for faut of pecunie [I] may not get yef I well wat whare pai are, \& pore \& sympyll has lytill voys" (Jasin, op. cit., note 5 above, p. 160). Lanfranc was among Bredon's donations to Oxford, but the reference to "lilium meum" in his will, though it may indicate Bernard's major work, does not specify it (Bullough, op. cit., note 33 above, p. 608). For a discussion of the medical faculty at Oxford, see Faye Marie Getz, 'The faculty of medicine before 1500', in J. I. Catto and Ralph Evans (eds), The history of the university of Oxford, vol. 2, Late medieval Oxford, Oxford, Clarendon, 1992.

sI The list of books given to Oxford by Humphrey, Duke of Gloucester, between 1439 and 1444 includes an entry for Gilles ("Aegidius [Corbeinensis]"), yet comes too late to be relevant here, given the date of 1379 for Daniel. See Vern L. Bullough, 'Duke Humphrey and his medical collections', Renaissance News, 1961, 14: 87-91, pp. 88-9.

52 As Gerhard Baader has proved; see his essay 'Zur Anatomie in Paris im 13. und 14. Jahrhundert', Medizinhistorisches Journal, 1968, 3: 40-53.

53 Ibid., pp. 45-6.

54 Ibid., pp. 48-9.

55 In his essay on the school of Salerno (Baader, op. cit., note 37 above, p. 136), Gerhard Baader credits Adalberto Pazzini with refuting this association. See Adalberto Pazzini, Ruggero di Giovanni Frugardo, maestro di chirurgia a Parma, e l'opera sua, Rome (Università), 1966.

${ }^{56}$ Charles H. Talbot, Medicine in medieval England, London, Oldbourne, 1967, p. 88. Talbot refers to Roger Frugardi as Roger of Salerno.

57 Though he is called "Magister Rogerus de Normannia" in the Middle English text (Jasin, op. cit., note 5 above, pp. 340, 345), a comparison of this portion of the treatise with corresponding passages in Book IV, chap. 19 of the Chirurgia confirms that Roger Frugardi of Parma is the medical figure meant here. See the edition of the Chirurgia by Karl Sudhoff, Beiträge zur Geschichte der Chirurgie im Mittelalter, vol. 2, Leipzig, J. A. Barth, 1914-18, p. 235. 


\section{The Middle English Liber uricrisiarum}

Several other references to scientific authorities in MS 225 deserve at least brief consideration in a survey of the sources of the text. In the section on the planets, Daniel cites Ptolemy and his Almagest, required reading for Oxford students as part of the quadrivium, ${ }^{58}$ and also donated by Simon Bredon to Oxford; ${ }^{59}$ Alfraganus (al-Farghani), the ninth-century Arab astronomer translated into Latin in the twelfth century by Daniel of Morley; ${ }^{60}$ and (in Middle English) "Algarell", most likely the Arab astrologer al-Rijal (Ibn abi-l-Rijal) who lived in the first half of the eleventh century and wrote the treatise $D e$ judiciis astrorum. ${ }^{61}$ The treatise was translated from Arabic into Latin via Castilian ${ }^{62}$ and, in its Latin form, was yet another of Simon Bredon's gifts to Oxford. ${ }^{63}$ Completing the list of authorities on astronomy mentioned in MS 225 is Richard of Wallingford ("Richard of Sant Albane"), the fourteenth-century abbot of St Albans, who wrote astronomical and mathematical texts. ${ }^{64}$

In addition, Daniel briefly cites standard authorities in other fields whose works were more widely accessible to clerics than many of the medical and astronomical texts named above. Among them are Bartholomeus Anglicus, the thirteenth-century English theologian who wrote the encyclopedic text De proprietatibus rerum; Nicholas Trevet, specifically his commentary on the pseudo-Boethian text De disciplina scolarium ${ }^{65}$ and Duns Scotus, the Franciscan theologian and philosopher of the late thirteenth and early fourteenth centuries. The numerous references to Aristotle in MS 225 often indicate his works on animals ("Kynd of bestys", "Buk of bestys"), although there is one reference to his Ethics. Oxford students would read both in the trivium, the former as part of the studia naturalia and the latter in the studia moralia. ${ }^{66}$ Finally, Daniel's citations of Isidore of Seville and his Etymologiae designate a work readily available in clerical circles in the Middle Ages (it, too, was donated by Bredon to Oxford), as is the case with the occasional reference to Holy Scripture or the Church fathers.

In short, Daniel's inclusion of Roger Frugardi, along with other prominent figures such as Gilbertus Anglicus and Taddeo Alderotti, establishes a connection between the Liber uricrisiarum and advances in medicine in Italy and France, particularly Montpellier. It also raises the possibility that Daniel acquired access to such texts while studying abroad, as noted above. Just as important, though, his inclusion of authorities representing advances in medicine on the Continent lends a certain currency (from a medieval

${ }^{58}$ Courtenay, op. cit., note 31 above, pp. 31-2.

59 Talbot and Hammond, op. cit., note 23 above, p. 322.

${ }^{60}$ Lauer, op. cit., note 34 above, p. 338.

${ }^{61}$ Though it is possible to identify the name "Algarell" as Algazel (al-Gazali), the connection is unlikely, since Manfred Ullmann describes al-Gazali as one of the twelfth-century Arabic theologians and philosophers who opposed astrology, seeing it as a competitor to religion. Manfred Ullmann, Die Natur- und Geheimwissenschaften im Islam, Leiden, Brill, 1972, p. 274.

${ }^{62}$ George Sarton, Introduction to the history of science, vol. 1, Baltimore, Williams and Wilkins for the Carnegie Institute of Washington, 1927-48, repr. Huntington, New York, Robert E. Krieger, 1975, pp. 715-16.

${ }^{63}$ Talbot and Hammond, op. cit., note 23 above, p. 321 .

${ }^{64}$ In the preface to his edition, J. D. North describes Richard of Wallingford as "the most original English mathematical astronomer of the late Middle Ages." Sec J. D. North, Richard of Wallingford: an edition of his writings with introductions, English translation, and commentary, vol. 1, Oxford, Clarendon, 1976, p. vii.

${ }^{65}$ Ruth J. Dean implies that the attribution of this commentary to Trevet may not be accurate; see her essay 'Nicholas Trevet, historian', in J. J. G. Alexander and M. T. Gibson (eds), Medieval learning and literature: essays presented to Richard William Hunt, Oxford, Clarendon, 1976, pp. 328-52, on p. 329.

${ }^{66}$ Courtenay, op. cit., note 31 above, p. 32. 


\section{Joanne Jasin}

perspective) to the Liber uricrisiarum, suggesting that in translating and compiling his uroscopy, Daniel deliberately went beyond the learned foundation in the Articella in transmitting to his readers sophisticated medical knowledge. ${ }^{67}$ (For astronomy, the reference to Richard of Wallingford certainly qualifies in this regard, and points to England rather than the Continent.) Furthermore, some of these later, non-Articella authorities share another trait in common, namely, the weight they give to a practical approach to medicine and the acquiring of medical knowledge, evident in their writings and exemplified by Gilles de Corbeil, Gilbertus Anglicus, Taddeo Alderotti, and Roger Frugardi. In this respect, too, they are especially appropriate for inclusion in a work like the Liber uricrisiarum, whose compiler clearly understands the significance of a theoretical basis for medical knowledge but who also recognizes the pragmatic needs of his audience and the value of the practical in a field like uroscopy, at once a science and a skill.

The knowledge that these learned sources transmit, generally acquired by the student of medicine in an academic setting, as discussed above, was to some extent modified by Daniel in the process of producing the vernacular text. In attempting to render the technical and theoretical knowledge of his sources as clearly as possible, to "undoo [it] in common spech, pat all men myght undyrstand \& knaw", 68 Daniel consistently demonstrates in the Liber uricrisiarum his attention to the practical considerations of his lay readers and adapts his source material accordingly. One representative example of his use of his sources, drawn from the De urinis by Isaac Judaeus, shows his technique of adaptation at work. The passage quoted below provides a definition of urine with which the treatise proper begins and appears in Chapter One entitled 'De essentia urine':

Urina est colamentum sanguinis ceterorumque humorum de nature quidem actionibus natum. Impossibile enim esse videtur, ut a sanguine, secundum quod oportet corpus nutriatur, nisi de utrisque prius choleribus \& phlegmate mundificetur \& a suo colamento seiungatur, quod urine liquor esse dicitur, quia urina liquorem ac hypostasim in se continet. Liquor autem est sanguini colamentum ut serum caseo, qui in venes descendit per maiorem venam, quae est in interioribus suis \& a renibus ad vesicam digreditur, sicut a stomacho ad intestina cibus. Sed tamen hi duo descensus a se invicem distare videntur, cum enim cibus in stomacho digeratur \& excoquatur antequam ad intestina ducatur, quia cibus naturaliter non est colamentum neque fex, urina vero non ita, sed potius colamentum quoddam, quod natura a sanguinis puritate separat. ${ }^{69}$

Perhaps the most striking feature of the Latin source as it defines what urine is, and the most striking difference between the Latin and Middle English versions, is the rigorous

\footnotetext{
${ }^{67}$ Siraisi's comments concerning the prominence of certain centres of medical education underscore the significance of Daniel's citation of authorities representing Italy and France. She indicates that Montpellier and the universities of northern Italy gained recognition for their contributions to medical learning in the late Middle Ages in part because they could claim a greater number of medical authors associated with their faculties than could other medical schools. Some of their works, e.g., commentaries, were themselves incorporated into the medical curriculum. Siraisi, op. cit., note 3 above, pp. 64-5.

${ }^{68}$ Jasin, op. cit., note 5 above, p. 142.

${ }^{69}$ Isaac Judaeus, Liber urinarum, in Omnia opera Ysaac, Lugduni, Bartholomeus Trot, 1515, ff. 156 ${ }^{r}-203^{r}$, on f. $157^{\vee} \mathrm{a}-\mathrm{b}$. Expansion of all abbreviations and suspensions in the edition is indicated by italics. Though the title Liber urinarum appears in this 1515 printed edition of Isaac's works, I have instead used the alternate title De
} 


\section{The Middle English Liber uricrisiarum}

analysis to which it subjects the definition. ${ }^{70}$ As Chapter One of the Latin text continues, it raises the issue of the adequacy of this definition of urine ("Hic primo queritur de diffinitione posita ab auctore in littera: videtur quod sit incompetens"), ${ }^{71}$ using as a basis for discussion the views of other medical authorities on the subject. As the chapter title indicates, this analysis of the definition examines the issue of the essence of urine, whether it is a filtering of the blood and other humours, as the first sentence states, or a filtering of the blood alone. It first cites Gerard, who posits that urine is indeed a filtering of the blood and the other humours, as the definition indicates, but then labels his statement "descriptio" rather than "diffinitio". The text continues by citing Theophilus, credited here with saying that urine is a filtering of the blood but not of the other humours ("Theophilus vero dicit quod est colamentum sanguinis \& non dicit aliorum humorum . . Et dicendum quod Theophilus sub sanguine comprehendit alios humores"). ${ }^{72}$ His statement rests on one's understanding of the term "blood", whether it is to be interpreted as the fluid in the body that contains and carries all the four humours, or as one of the four humours to be distinguished from choler, phlegm, and black bile. ${ }^{73}$ As the text clearly indicates, Theophilus' definition rests on an interpretation of the blood as containing all the humours; thus, at the same time that the blood is filtered of impurities in the production of urine, so are the other humours.

In this instance and elsewhere in the treatise, the Latin text attains a theoretical level of analysis with its questioning of the definition of its key term and its summary of the views of other authorities, particularly as it addresses a fundamental physiological question concerning the theory of the humours. It continues along the same lines with a discussion of the structure of urine as either simple or composite, referring in this context to an analogy introduced earlier between urine and the whey in milk or cheese ("... liquor [urine] est colamentum sanguinis sicut serum lactis vel casei"). ${ }^{74}$ The analogy, in accordance with the chapter's title, serves here to clarify one's understanding of the essence of urine: that it is separated from the humours and thus contains nothing of them, just as whey in the production of cheese does not contain anything of the substance of cheese. The comparison does not, however, end the discussion of what urine is; the text continues by citing Avicenna and explains that urine is an admixture, making careful

\footnotetext{
urinis to avoid possible confusion with the title 'Liber uricrisiarum' when referring to the Middle English treatise. Isaac's uroscopic text appears in a much more recent edition by Johannes Peine, Die Harnschrift des Isaac Judaeus, Borna-Leipzig, Robert Noske, 1919. Peine indicates in his introduction that he has based his text on the 1515 printed edition cited here, yet he neither includes nor refers to the extensive commentary by Petrus Hispanus, thirteenth-century physician and philosopher, in the 1515 edition. Though Peine's text is otherwise a valid one to use for the purposes of comparison, in this particular instance I use the 1515 edition since certain references in the corresponding section of the Middle English treatise suggest that Daniel had access to a version of Isaac's treatise with commentary. The corresponding passage in Peine's edition (pp. 10-11) is, however, identical to the one quoted above.

70 This analysis appears to be part of the commentary by Petrus Hispanus in the 1515 edition and does not appear in Peine's text.

${ }^{71}$ Isaac Judaeus, op. cit., note 69 above, f. $157^{\mathrm{v}} \mathrm{b}$.

72 Ibid.

${ }^{73}$ Margaret S. Ogden explains this potentially confusing distinction between "containing" and "contained" blood in her essay, 'Guy de Chauliac's theory of the humors', J. Hist. Med. allied Sci., 1969, 24: 272-91, pp. 276, 281-2.

${ }^{74}$ Isaac Judacus, op. cit., note 69 above, f. $157^{\mathrm{v}} \mathrm{b}$.
} 


\title{
Joanne Jasin
}

distinctions between the terms mixture and admixture. At this point, the Latin text shifts its focus away from the definition of urine to the location where it is produced in the body.

When we turn to the definition of urine presented in the Middle English Liber uricrisiarum in MS 225, what we find most revealing of Daniel's awareness of the lay readers in his audience is the shift in emphasis that he has introduced into the definition. The analysis of the essence and structure of urine in the Latin source gives way to an explanation of the process whereby, in a general sense, urine is produced in the body. In changing the emphasis, Daniel relies principally on the analogy between urine and whey and the concept of urine as a filtering or straining (and hence purifying) of the blood and the humours embodied in the Latin word "colamentum". The definition appears in Book One of the Middle English text, in Chapter Two entitled 'Quid sit urina':

\begin{abstract}
[A]ls sayis all auctours o pis faculte, pis is pe discripcion of uryn. Pe dyscripcion of a thynge is pe discryinge what a thynge is. Uryn is a lete, \& a suptel meltynge \& clensynge of pe blud \& of pe humours. I say a lete for pis skyll, for sumtym it passys owt of pe body sone after pat it is dronkyn, \& pat aught not for to be callyt uryn propirly, bod water or pyss. For when it is passyt sa sone, nouthyr it is decoctyd na dygestyd in pe veynes ne in pe reynes, ne colour of hyt is not profunded, id est, is not tynct, ne dep, ne dyed, as it suld kyndly be, $\&$ all is becaus pat it has not his kynd tym in pe body. Suptyl, for pe mare pat it is decoctyd \& degestyd in pe body, pe mare suptyl it is in hytself, \& pe bettyr profundyt in colour, as pu sall se in pe buk be all pe capitula, suptyl, id est, thyn \& bryght \& clere. A meltynge, a clensynge o pe blude in pe humours for pis skyll. For ryght as $\mathrm{p} u$ seis pat pe whay is wrongyn \& clensyd \& pressyt out of pe mylk be wyrkynge \& travalynge \& thrystynge \& pressynge out fra pe gross, pe thyk mater, pat is to say, fra pe uryn is wrongyne \& pressed \& clensyd out fra massa sanguinis, id est, fro clumpre, pe clod, pe stok, pe mater, \& pe well of blude. ${ }^{75}$
\end{abstract}

Though Daniel begins his description ${ }^{76}$ of the term "uryn" with a statement quite close to the wording in his source-compare "Uryn is a lete, \& a suptel meltynge \& clensynge of pe blud \& of pe humours" with "Urina est colamentum sanguinis ceterorumque humorum"- and though he explains the proper "cooking" of urine, as mentioned in his source, he retains nothing of the theoretical or substantive analysis of the physiological principle underlying the statement that appears in the Latin text. Moreover, the clause

\footnotetext{
75 Jasin, op. cit., note 5 above, pp. 53-4. To facilitate comparison of this lengthy passage with the Latin I provide the following modern English translation: "As say all authors in this field, this is the description of urine. The description of a thing is the describing or telling what a thing is. Urine is a flow, an issuing, and a thin or delicate melting and cleansing of the blood and of the humours. I say a flow or an issue for this reason, for sometimes it passes out of the body soon after one has drunk something, and that ought not to be called urine properly, but rather water or piss. For when it is passed so soon, it is neither cooked nor digested in the veins, nor in the kidneys; neither is the colour of it deepened, that is, tinted or dyed, as it should be naturally; and the reason for all this is that the urine has not had its natural time in the body. It is thin, for the more it is cooked and digested in the body, the thinner it is in itself, and the deeper in colour, as you shall see in this book in all the chapters (thin: that is, bright and clear). It is a melting, a cleansing of the blood in the humours for this reason: just as you see that the whey is wrung and cleansed and squeezed out of the milk through a working, labouring, thrusting, and squeezing out from the bulk [or] the thick matter, [so is] urine wrung and squeezed and cleansed out from massa sanguinis (the mass of blood), that is to say, from the lump, the mass, the stock, the matter, and the well of blood."

76 The term "discripcion" is here somewhat misleading, implying as it does that Daniel deliberately distinguishes between it and "diffinicion", when in fact he later calls both terms equivalent, thus ignoring the semantic distinction established in his source: "Diffinicion \& discripcion are all an, to say uryn a clensynge of pe blude \& all 4 humours wroght be of kynd in mannys body" (Jasin, op. cit., note 5 above, p. 54).
} 
"[A]ls sayis all auctours o pis faculte" proclaims full agreement among various medical authorities concerning the definition, when in fact the Latin text states otherwise. ${ }^{77}$ (In a similar statement appearing later in the same chapter, Daniel again disregards any differences among authorities in defining the term. $)^{78}$ In general, Daniel does not call into question the description of urine that he presents and consequently deletes those portions of Chapter One in De urinis in which the statements of Gerard, Theophilus, and Avicenna are carefully considered in turn. This key difference between Latin source and vernacular treatise is a clear example of Daniel's adaptation of source material to his audience; it implies his editorial decision that such fine points of discussion would be of little use to lay readers. Daniel does indeed submit the statement to analysis, but the analysis is stylistic in nature and sets out to clarify its key terms, virtually in the manner of an explication (note his explanation in the passage above of the terms "lete", "suptyl", and "meltynge", and the abundance of synonyms). This latter feature in particular, absent in Isaac's De urinis, is characteristic of the Liber uricrisiarum as a whole and most obviously demonstrates Daniel's efforts to make learned texts accessible to uneducated readers.

Daniel's explanation of the word "meltynge" in the passage above in particular exhibits his adaptation of the analogy between urine and whey present in De urinis. Instead of using the analogy to represent the essence of urine, as is the case in the Latin text, he employs it as a means to emphasize the process whereby urine is produced. The emphasis on process is consistent with the content of the Middle English passage as a whole in which Daniel has omitted discussion of the essence of urine altogether. This same emphasis is sustained in yet another example used to explain urine as a kind of filtering, suggested by the Latin term "colamentum"; this second analogy, moreover, is further evidence of Daniel's departure from the subject of the essence of urine and does not appear in his source:

Yhit anoper s[imi]l[i]tud, id est, exampyll (liknes), puttys autours of causynge \& gendrynge of uryn in mane, for pai call it a cribracion, id est, a syftynge \& a clensynge throgh a seve, \& for pis skyll. For ryght as pu seis pat throgh pe seve is pe clene separat $\&$ divysed, pe small fra pe gret, pe clene fra pe foule, \& pe coveabyll fra pe uncoveabyll, ryght pe same wyse in pe 2[nd] degestyoun, id est, in pe lyvere, is liquestracion \& divisioun, is pe maner of siftynge in secund degestyoun pat we call in Latyn epar, pe lyvere in Ynglyss. Of pis maner syftynge \& severynge \& wyrkynge, \& of pe 3 degestyons, see playn erly in pe folowand chapatyrs. . . ${ }^{79}$

The comparison offered here between the process of sifting and the production of urine in the body depicts in a manner easy for the reader to visualize the separation of impurities

\footnotetext{
77 The clause also indicates Daniel's use of a version of Isaac's De urinis with medieval commentary in which the differing views of the experts on the definition of urine are presented and analysed.

${ }^{78}$ Although it is incomplete, the statement confirms Daniel's access to a version of De urinis with commentary: "To pis forsaid discripcion of uryn, pat Gyles . . ., acordys well pe diffinicion pat Theofilus \& Ysaac ..." (Jasin, op. cit., note 5 above, p. 54). The ellipses here represent spaces (of 9-10 minims) left blank in the manuscript, apparently for later insertion of a word. They may simply indicate the scribe's difficulty in understanding words in the text he was copying, since at this point in the text HM 505 provides "gevyth" and "gyven", respectively (Hanna, op. cit., note 12 above, p. 196).

${ }_{79}$ Jasin, op. cit., note 5 above, p. 55. In modern English: "Authors provide yet another simile, that is, an example or illustration, of the cause and engendering of urine in man, for they call it a filtering, that is, a sifting and a cleansing through a sieve, and for this reason. For just as you see that, through the sieve, the clean is separated
} 
from nutrients that takes place in the second digestion. Regardless of the clarity of the image, however-it is the one with which the chapter entitled 'Quid sit urina' concludes-Daniel has not so much defined what urine is, as described in simplified terms how it is engendered. In so doing he remains faithful to the meaning of the word "colamentum" but modifies the accompanying text in his source to suit his particular rhetorical purpose. Though the degree of adaptation varies, Daniel's adherence to his governing principle in the treatment of his source remains constant throughout.

Vernacular medical texts like the Liber uricrisiarum represent one vital means whereby medical knowledge was circulated in late medieval England. Since, as Nancy Siraisi has pointed out, only a small proportion of medical practitioners from the thirteenth to the fifteenth centuries actually received their medical education at university, it is reasonable to assume that vernacular medical literature filled a critical need of lay practitioners for knowledge. ${ }^{80}$ Indeed, Siraisi suggests that the sheer abundance of vernacular literature in late medieval Europe in general implies the existence of a large group of practitioners with little or no Latin who depended on vernacular writings as their means of access to learned Latin texts, and thus as an important source of their medical training. ${ }^{81}$ Consequently, if in fact university-educated practitioners had previously enjoyed a monopoly on authoritative medical knowledge, the appearance of vernacular texts ensured that the monopoly was shattered. $^{82}$

In the hands of a highly capable compiler and translator like Henry Daniel, scholarly knowledge of uroscopy was made not only available but also useful to an expanded readership that included lay practitioners. The key to making such sophisticated learning both accessible and useful was, of course, language, and not simply the choice of English as the medium of communication. Daniel's control of language, manifested in the methods of translation he applied to his Latin sources and his modification of the content in those sources, enabled him to place authoritative knowledge in the hands of the individual reader. Moreover, because of his statements in his prologue and the declaration of rhetorical purpose in the treatise proper in MS 225, we have proof of his intent in producing the Liber uricrisiarum and direct knowledge of his keen awareness of his audience.

The number of extant manuscripts of the Liber uricrisiarum attest the impact of Daniel's work during the late Middle Ages in England: Getz calls it "the most widely circulated of [the] pastoral medical texts"; ${ }^{83}$ Hanna characterizes its circulation as "staggering". ${ }^{84}$ This wide circulation indicates that Daniel was indeed successful in conveying medical learning to his readers, not only the foundations of learning contained in the Articella but also some of the more recent contributions to medical knowledge

\footnotetext{
and divided, the small from the large, the clean from the unclean, and the suitable from the unsuitable, in the same way in the second digestion, that is, in the liver, occurs melting and dividing, i.e., that manner of sifting in the second digestion, [located in] that which we call in Latin epar, in English, the liver. Of this manner of sifting and dividing and working, and of the three digestions, see clearly in the following chapters."

${ }^{80}$ Siraisi, op. cit., note 3 above, p. 31.

"I lbid., pp. 20, 52.

82 Ibid., p. 34.

${ }^{8.3}$ Getz, op. cit., note 9 above, p. 12.

${ }^{x+}$ Hanna, op. cit., note 12 above, p. 185.
} 
represented by the citations of figures associated with the medical faculties of Montpellier and northern Italy. The accomplishment of the Liber uricrisiarum, a treatise that because of its subject matter (i.e., uroscopy) embraces both science and skill, ${ }^{85}$ is not merely that it transmits sophisticated medical knowledge but that it does so in a manner useful to its readers.

\footnotetext{
xs This description of uroscopy as both science and skill calls to mind the statements of Linda Ehrsam Voigts and Michael R. McVaugh regarding the classification of uroscopic texts in the medieval medical corpus, namely, that if we consider popular recipe books on the one hand and university texts on the other to represent the "poles of a continuum", then uroscopic texts can be said to occupy the middle ground. See Linda E. Voigts and Michael R. McVaugh, A Latin technical phlebotomy and its Middle English translation, Philadelphia, Transactions of the American Philosophical Society, 1984, no. 74, part 2, p. 21.
} 